Situs Jurnal : $\underline{\text { http://ejournal.stiepancasetia.ac.id/index.php/jieb }}$

Jilid 5 Nomor 3 November 2019

Hal 395 - 408

\title{
PENGARUH CAPITAL ADEQUACY DAN LOAN TO DEPOSIT RATIO TERHADAP RETURN ON ASSET: STUDI PADA BANK BPR DI INDONESIA
}

\section{Sri Suryani*, Grahita Candrain, dan Junianto Tjahyo Darsono}

Abstract: Profitability is bank performance indicator that effort in certain time. Profitability is known by Return On Asset (ROA). Return On Asset (ROA) is influenced by Capital Adequacy Ratio (CAR) and Loan to Deposit Ratio (LDR). To improve the influence Capital Adequacy Ratio (CAR) and Loan to Deposit Ratio (LDR) need the research. This research uses quantitative method. The population is all the BPR in Indonesia. The population are consist of $100 \mathrm{BPR}$. Technique of sampling is used census. This research sample is $100 \mathrm{BPR}$. The data collection technique is questioner. Data is analyzed by linear regression. The results of this research shows that Capital Adequacy Ratio (CAR) and Loan to Deposit Ratio (LDR) have influence significantly to the Return On Asset (ROA). Capital Adequacy Ratio (CAR) has not influence significantly to the Return On Asset (ROA). Loan to Deposit Ratio (LDR) have influence significantly to the Return On Asset (ROA).Loan to Deposit Ratio (LDR) is more dominant variable than Capital Adequacy Ratio (CAR) influences Return On Asset (ROA).

Keywords: Return On Asset (ROA), Capital Adequacy Ratio (CAR), Loan to Deposit Ratio $(L D R)$

Abstrak: Profitabilitas adalah indikator kinerja bank yang berusaha pada waktu tertentu. Profitabilitas dikenal dengan Return On Asset (ROA). Return On Asset (ROA) dipengaruhi oleh Capital Adequacy Ratio (CAR) dan Loan to Deposit Ratio (LDR). Untuk meningkatkan pengaruh Capital Adequacy Ratio (CAR) dan Loan to Deposit Ratio (LDR) perlu penelitian. Penelitian ini menggunakan metode kuantitatif. Populasi adalah semua BPR di Indonesia. Populasi terdiri dari 100 BPR. Teknik pengambilan sampel menggunakan sensus. Sampel penelitian ini adalah 100 BPR. Teknik pengumpulan data adalah kuesioner. Data dianalisis dengan regresi linier. Hasil penelitian ini menunjukkan bahwa Capital Adequacy Ratio (CAR) dan Loan to Deposit Ratio (LDR) berpengaruh signifikan terhadap Return On Asset (ROA). Capital Adequacy Ratio (CAR) tidak berpengaruh signifikan terhadap Return On Asset (ROA). Loan to Deposit Ratio (LDR) memiliki pengaruh signifikan terhadap Return On Asset (ROA). Rasio Pinjaman terhadap Deposito (LDR) lebih dominan daripada variabel Capital Adequacy Ratio (CAR) mempengaruhi Return On Asset (ROA).

Kata kunci: Return On Asset (ROA), Capital Adequacy Ratio (CAR), Loan to Deposit Ratio $(L D R)$

\section{Latar Belakang}

Semua perusahaan menjalankan bisnis dengan harapan memperoleh laba yang maksimal. Laba atau profit dapat diketahui melalui kinerja keuangan. Pengukuran kinerja keuangan merupakan aktivitas penting dalam perusahaan. Pengukuran kinerja keuangan dapat dijadikan indikator memperbaiki kegiatan operasional perusahaan. Dengan perbaikan kinerja operasional 
diharapkan perusahaan dapat mengalami pertumbuhan keuangan lebih baik dan dapat bersaing dengan perusahaan lain melalui efisiensi dan efektivitas.

Kinerja keuangan diindentikasi dengan menganalisis laporan keuangan.Manulang (2008: 308) menegaskan pada umumnya laporan keuangan terdiri dari neraca dan perhitungan laba rugi, analisis kekayaan atau perubahan posisi keuangan dan rekonsiliasi modal sendiri atau perubahan modal serta laporan arus kas perusahaan.Neraca menunjukkan jumlah aktiva, hutang dan modal dari suatu perusahaan pada tanggal tertentu.Perhitungan laporan laba rugi memperlihatkan hasil-hasil yang telah dicapai oleh perusahaan serta biaya-biaya yang terjadi selama periode tertentu. Rekonsiliasi modal sendiri merupakan laporan perubahan atas modal sendiri yang terjadi terutama akibat adanya laba rugi tahun berjalan, selisih harga atas nilai kekayaan yang belum direalisasikan, perubahan kekayaan yang tidak diperkenankan, penambahan modal disetor, dan pembayaran deviden, laporan arus kas bank menunjukkan jumlah penerimaan dan pengeluaran.

Keuntungan perusahaan dapat dilihat dari perhitungan rasio profitabilitas. Rasio profitabilitas merupakan rasio yang digunakan untuk mengukur kemampuan perusahaan dalammenghasilkan laba dari aktivitas normal bisnisnya. Tujuan operasional dari sebagian besar perusahaan adalah untuk memaksimalisasi profit baik profit jangka pendek maupun proft jangka panjang. Manajemen dituntut untuk meningkatkan imbal hasil (return) bagi pemilik perusahaan sekaligus juga meningkatkan kesejahteraan karyawan. Ini dapat dicapai apabila perusahaan memperoleh laba dalam aktivitas bisnisnya (Hery, 2015: 226).

Profitabilitas dapat diketahui melalui perhitungan Return OnAsset (ROA).ROA merupakan kemampuan dari modal yang diinvestasikan ke dalam seluruh aktiva perusahaan untuk menghasilkan keuntungan.Semakin tinggi laba yang dihasilkan, maka semakin tinggi pula ROA, hal itu berarti bahwa perusahaan semakin efektif dalam penggunaan aktiva untuk menghasilkan keuntungan.ROA dihitung berdasarkan perbandingan laba sebelum pajak dan rata-rata total assets.

Profitabilitas dapat diukur dengan ROA.ROA mengukur kemampuan manajemen bank dalam mengelola aset-asetnya guna memperoleh keuntungan secara keseluruhan (Dendawijaya, 2003: 120).Hasil pengembalian atas aset merupakan rasio yang menunjukkan seberapa besar kontribusi aset dalam menciptakan laba bersih. Dengan kata lain, rasio ini digunakan untuk mengukur seberapa besar jumlah laba bersih yang akan dihasilkan dari setiap rupiah dana yang tertanam dalam total aset. Semakin tinggi hasil pengembalian atas aset berarti semakin tinggi pula jumlah laba bersih yang dihasilkan dari setiap rupiah dana yang tertanam dalam total aset. Sebaliknya, semakin rendah hasil pengembalian atas aset berarti semakin rendah pula jumlah laba bersih yang dihasilkan dari setiap rupiah dana yang tertanam dalam total aset.

Return OnAsset dapat dipengaruhi oleh Capital Adequacy Ratio (CAR), Biaya Operasi dibanding Pendapatan Operasi, Net Interest Margin, NonPerforming Loan dan Loan to Deposit Ratio. Penelitian terdahulu dilakukan Prakasa (2007) membahas tentang Analisis Pengaruh Rasio-rasio Keuangan Terhadap Kinerja Bank Umum di Indonesia (Studi Empiris Bank-bank Umum Yang Beroperasi Di Indonesia). Tujuan dari penelitian ini adalah untuk membuktikan pengaruh rasio keuangan Capital Adequacy Ratio, Biaya Operasi dibanding Pendapatan Operasi, Net Interest Margin, NonPerforming Loan (NPL) dan Loan to Deposit Ratio terhadap kinerja bank yang diukur dengan Return On Asset serta variabel-variabel manakah yang paling dominan berpengaruh terhadap Return On Asset.

Dari hasil uji F didapat nilai F hitung sebesar 158,074 dengan $\mathrm{P}$ value sebesar 0,001. Hal ini berarti nilai $\square$ value kurang dari 0,05 yang menunjukkan bahwa variabel Capital Adequacy Ratio, Biaya Operasi dibanding Pendapatan Operasi (BOPO),Net Interest Margin, Non Performing Loan (NPL) dan Loan to Deposit Ratio secara bersama-sama mempunyai pengaruh yang berarti terhadap Return On Asset. Berdasarkan hasil uji t disimpulkan bahwa Non 
Performing Loan, NetInterest Margin dan Biaya Operasi dibanding Pendapatan Operasi berpengaruh secara parsial terhadap Return On Asset sedangkan CapitalAdequacy Ratio dan Loan to Deposit Ratio tidak berpengaruh secara parsial. Tanda positif pada variabel Non Performing Loan dapat dijelaskan bahwa ROA pada tahun tersebut tetap tinggi meskipun nilai NPL juga tinggi. Hal ini dapat terjadi karena rata-rata NPL pada tahun tersebut masih dalam batas NPL maksimum yang disyaratkan oleh Bank Indonesia yaitu 4,14\% sehingga ROA tetap tinggi.

Penelitian Rindhatmono (2005) menganalisis Analisis Faktor-Faktor yang Mempengaruhi Profitabilitas Bank Pasca Merger di Indonesia.Kecenderungan bisnis untuk melakukan merger dan akuisisi, terjadijuga pada bisnis keuangan terutama bank. Di Indonesia, proses konsolidasiperbankan dilakukan melalui Arsitektur Perbankan Indonesia (API). Karena adanyaperbedaan profitabilitas bank yang telah melakukan merger dan akuisisidengan bank yang tidakmelakukan merger dan akuisisi, maka maksud dari penelitian ini adalah untuk menguji danmenganalisis pengaruh efisiensi usaha (BOPO), risiko kredit (NPL), risiko pasar(NIM), Likuiditas (LDR), market share (TA) dan modal (CAR) terhadap profitabilitas(ROA) bank pasca merger di Indonesia. Penelitian dilakukan terhadap bank yangtelah melakukan M dan A dengan pooling data dari tahun 1999-2004 dan dianalisisdengan metode regresi berganda.

Hasil penelitian menunjukkan bahwa BOPO, NPL,NIM, CAR dan market share mempunyai pengaruh yang signifikan terhadapprofitabilitas (ROA) bank pasca merger di Indonesia, sedangkan LDR tidak signifikan.Secara keseluruhan, bank pasca merger di Indonesia mempunyai ratio BOPO, NPL,NIM, LDR, CAR dan MS, belum dapat memenuhi batasan-batasan yang telahditetapkan oleh regulator.Hal ini membuktikan bahwa bank pasca merger diIndonesia yang telah melakukan merger sejak tahun 1999, belum dapatmelaksanakan fungsi intermediasi secara optimal dan persoalan merger bukanmerupakan permasalahan keuangan semata-mata, tetapi juga kepada persoalan nonfinansial.

Berdasarkan hasil penelitian di atas, terbukti bahwa variabel Capital Adequacy Ratio, Biaya Operasi dibanding Pendapatan Operasi, Net Interest Margin, Non Performing Loan dan Loan to Deposit Ratio secara bersama-sama mempunyai pengaruh yang berarti terhadap Return On Asset. Berdasarkan hasil uji t disimpulkan bahwa Non Performing Loan, NetInterest Margin dan Biaya Operasi dibanding Pendapatan Operasi berpengaruh secara parsial terhadap Return On Asset. Namun demikianCapitalAdequacy Ratio dan Loan to Deposit Ratio tidak berpengaruh secara parsial. CapitalAdequacy Ratio dan Loan to Deposit Ratio tidak berpengaruh secara parsial menjadi bahan penelitian selanjutnya.

\section{Kajian Literatur}

Laporan keuangan melaporkan transaksi bisnis atau peristiwa ekonomi yang terjadi dalam suatu periode waktu tertentu. Transaksi bisnis atau peristiwa ekonomi yang terjadi ini dituangkan dalam bentuk angka-angka. Untuk menilai kondisi keuangan dan kinerja perusahaan, angka-angka yang ada dalam laporan keuangan akan menjadi lebih bermakna jika angka-angka tersebut saling dibandingkan. Rasio keuangan didesain untuk menjelaskan hubungan antara item-item pada laporan keuangan (neraca dan laporan rugi/laba) (Siragih, dkk, 2005: 222).

Rasio keuangan merupakan suatu perhitungan rasio dengan menggunakan laporan keuangan yang berfungsi sebagai alat ukur dalam menilai kondisi keuangan dan kinerja perusahaan.Rasio keuagan adalah angka yang diperoleh dari hasil perbandingan antara satu pos laporan keuangan dengan pos lainnya yang mempunyai hubungan yang relevan dan signifikan.Perbandingan dapat dilakukan antara satu pos dengan pos lainnya dalam satu laporan keuangan atau antar pos yang ada di antara laporan keuangan (Hery, 2015: 161). 
Secara garis besar jenis rasio keuangan yang sering digunakan untuk menilai kondisi keuangan dan kinerja perusahaan adalah:

1. Rasio Likuiditas

Rasio likuiditas merupakan rasio untuk mengukur kemampuan bank dalam memenuhi kewajiban jangka pendeknya pada saat ditagih. Dengan kata lain, bank dapat membayar kembali pencarian dana deposannya pada saat ditagih serta dapat mencukupi permintaan kredit yang telah diajukan. Semakin besar rasio ini semakin likuid (Kasmir, 2011: 286).

LDR merupakan rasio yang mengukur kemampuan bank untuk memenuhi kewajiban keuangan yang harus dipenuhi. Kewajiban tersebut berupa call money yang harus dipenuhi pada saat adanya kewajiban kliring. Pemenuhannya dilakukan dari aktiva lancar yang dimiliki perusahaan. LDR dihitung dari perbandingan antara total kredit dengan dana pihak ketiga. Total kredit yang dimaksud adalah kredit yang diberikan kepada pihak ketiga (tidak termasuk kredit kepada bank lain). Dana pihak ketiga yang dimaksud yaitu antara lain giro, tabungan dan deposito (tidak termasuk antarbank). Rumus untuk mencari Loan to Deposit Ratio sebagai berikut:

Loan To Deposit Ratio $=\frac{\text { Total loans }}{\text { Total deposit }+ \text { equity }} \times 100 \%$

2. Rasio Solvabilitas

Rasio solvabilitas atau rasio struktur modal disebut juga Rasio Leverage merupakan rasio yang menggambarkan kemampuan perusahaan dalam memenuhi seluruh kewajibannya. Sama hanya dengan rasio likuditas, rasio solvabilitas juga diperlukan untuk kepentingan analisis kredit atau analisis risiko keuangan.

3. Rasio Aktivitas

Rasio aktivitas merupakan rasio yang digunakan untuk mengukur tingkat efisiensi atas pemanfaat sumber daya yang dimiliki perusahaan atau untuk menilai kemampuan perusahaan dalam menjalankan aktivitasnya sehari-hari. Rasio ini dikenal juga sebagai rasio pemanfaatan aset, yaitu rasio yang digunakan untuk menilai efektivitas dan intensitas aset perusahaan dalam menghasilkan penjualan.

4. Rasio Profitabilitas

Penggunaan rasio profitabilitas dapat dilakukan dengan menggunakan perbandingan antara berbagai komponen yang ada di laporan keuangan neraca dan laporan laba rugi. Pengukuran dapat dilakukan untuk beberapa periode operasi.Tujuannya adalah agar terlihat perkembangan perusahaan dalam rentang waktu tertentu, baik penurunan atau kenaikan, sekaligus mencari penyebab perubahan tersebut (Kasmir, 2015: 196).

Rasio Profitabilitas terdiri atas :

a. Hasil pengembalian atas aset (Return On Assets)

Rasio ini merupakan rasio yang menunjukkan hasil (return) atas penggunaan aset perusahaan dalam menciptakan laba bersih dengan kata lain, rasio ini digunakan untuk mengukur seberapa besar jumlah laba bersih yang akan dihasilkan dari setiap rupiah dana yang tertanam dalam total aset. Resturn On Asset (Hasil Pengembalian atas Aset) dihitung dengan menggunakan rumus sebagai berikut.

Hasil pengembalian atas aset $=\frac{\text { Laba bersih }}{\text { Total aset }}($ Hery, 2015: 168) 
b. Hasil Pengembalian atas Ekuitas (return on equity)

Rasio ini merupakan rasio yang menunjukkan hasil (return) atau penggunaan ekuitas perusahaan dalam menciptakan laba bersih. Dengan kata lain, rasio ini digunakan untuk mengukur seberapa besar jumlah laba bersih yang akan dihasilkan dari rupiah dana yang tertanam dalam total ekuitas (Hery, 2015: 168). Return On Equityt (Hasil Pengembalian atas Aset) dihitung menggunakan rumus:

Hasil pengembalian atas ekuitas $=\frac{\text { Laba bersih }}{\text { Total ekuitas }}($ Hery, 2015: 235).

Berdasarkan uraian pada kajian teori dan pembahasan penelitian relevan di atas dirumuskan hipotesis penelitianini sebagai berikut.

1. CAR dan LDR berpengaruh signifikan terhadap ROA pada BPR di Indonesia tahun 2015.

2. CAR berpengaruh signifikan terhadap ROA pada BPR di Indonesia tahun 2015.

3. LDR berpengaruh signifikan terhadap ROA pada BPR di Indonesia tahun 2015.

\section{Metode Penelitian}

Penelitian menggunakan metode ekspalanatif dengan teknik survey untuk menganalisis hubungan kausal antara kompensasi dengan kinerja karyawan, hubungan kausal antara CAR dengan ROA, hubungan kausal antara LDR dan ROA, dan hubungan kausal antara CAR dan LDR dengan ROA pada BPR di Indonesia. Penelitian ini menganalisis pengaruh CAR dan LDR terhadap ROA BPR di Indonesia untuk periode tahun 2015.CAR, LDR, dan ROA termasuk dalam lingkup pembahasan Manajemen Keuangan.Dengan demikian ruang lingkup penelitian ini adalah manajemen Keuangan.Variabel penelitian ini ada dua yaitu variabel independen dan variabel dependen. Variabel bebas ada 2 yaitu Capital Adequacy Ratio dilambangkan dengan (X1) dan Loan to Deposit Ratio dilambangkan dengan (X2). Variabel terikat penelitian ini adalah Return On Asset dilambangkan dengan (Y).

Definisi Konseptual Penelitian pada penelitian ini adalah sebagai berikut:

1. Return On Asset

Rasio ini merupakan rasio yang menunjukkan hasil (return) atas penggunaan aset perusahaan dalam menciptakan laba bersih dengan kata lain, rasio ini digunakan untuk mengukur seberapa besar jumlah laba bersih yang akan dihasilkan dari setiap rupiah dana yang tertanam dalam total aset. Resturn On Asset (Hasil Pengembalian atas Aset) dihitung dengan menggunakan rumus sebagai berikut.

Hasil pengembalian atas aset $=\frac{\text { Laba bersih }}{\text { Total aset }}($ Hery, 2015: 168).

\section{Capital Adequacy Ratio}

CAR adalah rasio atau perbandingan antara modal bank dengan aktiva tertimbang menurut resiko (ATMR). CAR menjadi pedoman bank dalam melakukan ekspansi di bidang perkreditan.Dalam prakteknya perhitungan CAR yang oleh Bank Indonesia disebut Kewajiban Penyediaan Modal Minimum Bank (KPMM) tidaklah sederhana.KPMM adalah perbandingan antara Modal dengan Aktiva Tertimbang Menurut Resiko. Baik ATMR maupun Modal Bank memerlukan rincian dan kesamaan pengertian apa yang masuk sebagai komponen untuk menghitung ATMR dan bagaimana menghitungnya. Begitu juga Modal, 
perlu dirinci apa yang dapat digolongkan dan diperhitungkan sebagai Modal Bank. Petunjuk mengenai hal ini diatur dasar-dasarnya oleh Bank Indonesia melalui ketentuan SE BI No. 26/1/BPPP tanggal 29 Mei 1993.Dalam menilai capital suatu bank dapat digunakan rumus Capital Adequacy Ratio (CAR). Rumus CAR :

Capital Adequacy Rasio $(\mathrm{CAR})=\frac{\text { Modal }}{\text { Aktiva Tertimbang Menurut Resiko }}$

\section{Loan to Desposit Rasio}

Loan to Deposit Ratio merupakan rasio untuk mengukur komposisi jumlah kredit yang diberikan dibandingkan dengan jumlah dana masyarakat dan modal sendiri yang digunakan. Besarnya Loan to Deposit Ratio menurut peraturan pemerintah maksimum adalah $110 \%$ (Kasmir, 2011: 290). LDR merupakan rasio yang mengukur kemampuan bank untuk memenuhi kewajiban keuangan yang harus dipenuhi. Kewajiban tersebut berupa call money yang harus dipenuhi pada saat adanya kewajiban kliring, dimana pemenuhannya dilakukan dari aktiva lancar yang dimiliki perusahaan. LDR dihitung dari perbandingan antara total kredit dengan dana pihak ketiga. Total kredit yang dimaksud adalah kredit yang diberikan kepada pihak ketiga (tidak termasuk kredit kepada bank lain). Dana pihak ketiga yang dimaksud yaitu antara lain giro, tabungan dan deposito (tidak termasuk antarbank). Rumus untuk mencari Loan to Deposit Ratio sebagai berikut:

Loan To Deposit Ratio $=\frac{\text { Total loans }}{\text { Total deposit }+ \text { equity }} \times 100 \%($ Kasmir, 2011: 290).

Data dalam penelitian ini diperoleh dari laporan Keuangaan Bank. Dengan demikian teknik pengumpulan data yang digunakan adalah dokumentasi tentang laporan keuangan yang barkaitan dengan ROA, CAR, dan LDR. Dokumentasi adalah teknik mencari data mengenai hal-hal atau variabel yang berupa catatan, transkrip, bukum surat kabar, majalah, prasasti, notulenrapat, lengger, agenda, dan lain-lain (Arikunto, 2010: 274).

Sampel penelitian adalah bagian dari populasi yang menjadi objek penelitian. Teknik pengambilan sampel menggunakan metode sensus.Sampel penelitian ini berjumlah 100 buah bank BPR seluruh Indonesia.

Teknik Analisis Data yang digunakan dalam penelitian ini adalah:

1. Analisis Deskripsi

Analisis deskriptif adalah analisis yang dilakukan untuk menjelaskan data dri satu variabel. Ukuran deskriptif yang digunakan untuk mendeskripsikan data penelitian ini adalah frekuensi dan rata-rata (Sanusi, 2012: 116).

2. Uji Asumsi Klasik

a. Uji Normalitas

Uji normalitas bertujuan untuk mengetahui apakah datayang terkumpul berdistribusi normal atau tidak.Dengan uji normalitas akandiketahui sampel yang diambil berasal dari populasi yang berdistribusi normalatau tidak.Apabila pengujian normal, maka hasil perhitungan statistik dapatdigeneralisasikan pada populasinya.Uji normalitas dalam penelitian ini dilakukan dengan Chi Kuadrat.Kriteria yang digunakan adalah Chi Kuadrat hitung > r Chi Kuadrat tabel (Sugiyono, 2008: 199). Selain itu uji normalitas dilakukan untuk melihat apakah nilai residual terdistribusi normal atau tidak dengan Model regresi yang baik memeiliki residual yang terdistribusi normal.Uji ini dapat dilakukan dengan uji 
histrogram, uji normal P Plot, Skewness, dan Kurtosis atau uji kolmogorof Smirrnov (Kurniawan, 2014: 156).

b. Auto Korelasi

Uji aotokorelasi dilakukan untuk mendeteksi variabel dependen tidak berkorelasi dengan variabel itu sendiri. Nilai korelasi variabel tidak dihubungkan dengan variabel itu sendiri baik nilai periode sebelumnya atau periode sesudahnya. Untuk mengetahui gejala autokorelasi dilakukan dengan menggunakan ui Durbin-Watson (DW). Uji ini menghasilkan nilai DW hitung $(d)$ dan nilai DW tabel $\left(d_{i}\right.$ dan $d_{v}$ ) (Santoso dan Ashari, 2005: 240).

c. Multikorelasi

Uji multikolinieritas digunakan untuk mengetahui ada atau tidak variabel independen yang memiliki kemiripan dengan variabel independen yang lain dalam satu model. Selain itu uji multikolinieritas juga bertujuan untuk menghindari bias dalam proses pengimbilan kesimpulan mengenai pengaruh uji parsial masing-masing variabel independen terhadap variabel dependen. Nugroho (2005:58) menyatakan bahwa uji multikolenieritas dapat dilakukan dengan menggunakan kriteria bahwa nilai Variance Infation Factor (VIF) $<10$ dan nilai tolerance < nilai VIP, nilai tolerance juga tidak kurang dari 0,1.

\section{Analisis Regresi Linier Ganda}

Analisis regresi berganda merupakan perluasan dari regersi sederhana yaitu dengan menambah jumlah variabel bebas (regresi berganda) (Sanusi, 2012: 134). Analisis data penelitian ini menggunakan analisis regresi berganda dengan persamaan kuadrat Pengujian Hipotesis

a. Nilai F hitung $>$ F table dengan nilai $\rho<0,05$, hipotesis alternatif $(\mathrm{Ha})$ diterima dan model penelitian yang dibuat sudah tepat. Jika nilai $F$ hitung $<F$ tabel dan $\rho>0,05$, hipotesis alternatif (Ha) ditolak (Misbahuddin dan Hasan, 2013: 157).

b. Nilai t hitung $>\mathrm{t}$ tabel dan signifikansi $>0,05$, maka hipotesis yang menunjukkan pengaruh parsial diterima.

c. Nilai t yang terbesar menunjukkan variabel dominan mempengaruhi variabel independen

\section{Hasil Penelitian}

Uji normalitas dilakukan untuk melihat apakah nilai residual terdistribusi normal atau tidak dengan Model regresi yang baik memeiliki residual yang terdistribusi normal. Uji ini dapat dilakukan dengan uji normal P Plot. Jika titik-titik pada grafik PPlot mengikuti garis lurus, maka data dinayatakan normal. Titik-titik pada grafik PPlot di bawah ini mengikuti garis lurus sehingga data penelitian ini dikatakan berdistribusi normal.
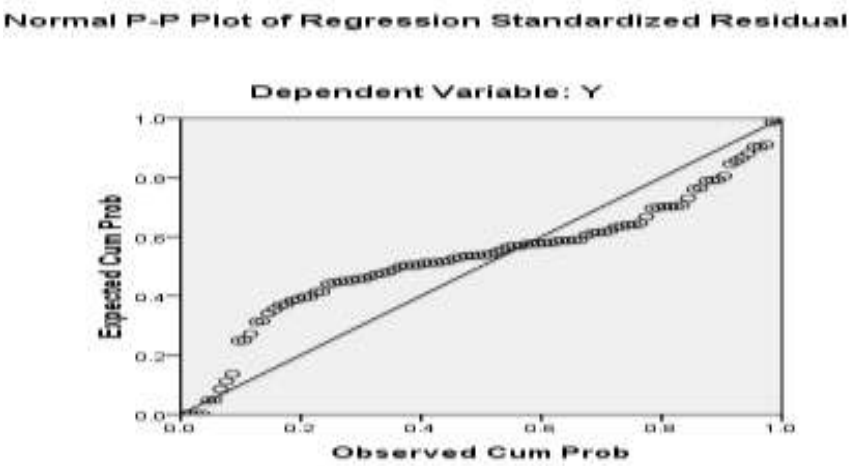

Gambar 1. Hasil Uji Normalitas 
Autokorelasi terjadi apabila korelasi diantara data pengamatan.Munculnya suatu data dipengaruhi oleh data sebelumnya Jika ada autokorelasi maka dapat dikatakan bahwa koefisien korelasi yang dipengaruhi kurang akurat.Uji autokorelasi dilakukan dengan membandingkan nilai Durbin Watson hitung dengan nilai Durbin Watson pada tabel.Kriteria yang digunakan adalah jika Nilai Durbin Watson hitung berada di luar du dan dl yang terdapat pada tabel Durbin Watson maka, data penelitian ini terbebas dari gejala autokorelasi.Berdasarkan tabel model summary analisis regresi diketahui nilai Durbin Watson hitung sebesar 2,029. Nilai Durbin Watson pada tabel dengan $n=100$ dan variabel bebas atau $\mathrm{k}-2$, nilai du sebesar 1,63 dan nilai dl sebesar 1,72. Nilai Durbin Watson hitung sebesar 2,029berada di luar 1,63 dan 1,72. Jadi data penelitian ini tidak menunjukkan gejala autokorelasi

Tabel 1. Hasil Uji Multikolineritas

\begin{tabular}{lcc}
\hline \multicolumn{1}{c}{ Variabel } & Tolerance & VIF \\
\hline Capital Adequacy Ratio $(\mathrm{X} 1)$ & 0,993 & 1,007 \\
\hline Loan to Deposit Ratio $(\mathrm{X} 2)$ & 0,993 & 1,007 \\
\hline
\end{tabular}

Uji multikolineritas dilakukan membandingkan nilai VIF pada tabel koefisien hasil analisis regresi dengan bilangan 10 . Kriteria menentukan gejala multikolineritas adalah jika nilai VIF $<10$ maka tidak terjadi gejala multikolineritas. Nilai VIF variabel Capital Adequacy Ratio 1,007 dan Loan to Deposit Ratio sebesar 1,007.Nilai VIF Capital Adequacy Ratio dan Loan to Deposit Ratio <10.Ini menunjukkan tidak terjadi multikolineritas pada variabel bebas penelitian ini.

Tabel 2. Hasil Uji Multikolineritas

\begin{tabular}{lcc}
\hline \multicolumn{1}{c}{ Variabel } & Tolerance & VIF \\
\hline Capital Adequacy Ratio $(\mathrm{X} 1)$ & 0,993 & 1,007 \\
\hline Loan to Deposit Ratio $(\mathrm{X} 2)$ & 0,993 & 1,007 \\
\hline
\end{tabular}

Uji multikolineritas dilakukan membandingkan nilai VIF pada tabel koefisien hasil analisis regresi dengan bilangan 10. Kriteria menentukan gejala multikolineritas adalah jika nilai VIF < 10 maka tidak terjadi gejala multikolineritas. Nilai VIF variabel Capital Adequacy Ratio 1,007 dan Loan to Deposit Ratio sebesar 1,007.Nilai VIF Capital Adequacy Ratio dan Loan to Deposit Ratio <10.Ini menunjukkan tidak terjadi multikolineritas pada variabel bebas penelitian ini.

Tabel 3 Rata-rata Capital Adequacy Ratio (CAR) BPR di Indonesia tahun 2015

\begin{tabular}{clcc}
\hline No. & Nilai Capital Adequacy Ratio (CAR) & Frekuensi & Persentase \\
\hline 1. & CAR $<35,2$ & 60 & $60 \%$ \\
\hline 2. & CAR $>35,52$ & 40 & $40 \%$ \\
\hline$\quad$ Jumlah & 100 & $100 \%$ \\
\hline & Rata-rata & 35,52 & \\
\hline
\end{tabular}

Berdasarkan tabel di atas diketahui rata-rata Capital Adequacy Ratio(X1) 35,52. Jumlah BPR yang mencapai CAR <35,2 berjumlah 60 buah. Jumlah BPR yang mencapai CAR > 35,52 berjumlah 40 buah. Dengan demikian jumlah BPR yang mencapai nilai CAR di atas rata-rata hanya 40 buah atau $40 \%$ dari 100 BPR di Indonesia. 
Tabel 4. Rata-rata Loan to Deposit Ratio (LDR) BPR di Indonesia tahun 2015

\begin{tabular}{clcc}
\hline No. & Loan to Deposit Ratio (LDR) & Frekuensi & Persentase \\
\hline 1. & LDR $<75,1$ & 46 & $46 \%$ \\
\hline 2. & LDR $>75,1$ & 54 & $54 \%$ \\
\hline & Jumlah & 100 & $100 \%$ \\
\hline & Rata-rata & 75,1 & \\
\hline
\end{tabular}

Berdasarkan tabel di atas diketahui rata-rata Loan to Deposit Ratio (LDR) (X2) 75,1. Jumlah BPR yang mencapai LDR $<75,1$ berjumlah 46 buah. Jumlah BPR yang mencapai LDR $>75,1$ berjumlah 54 buah. Dengan demikian jumlah BPR yang mencapai nilai LDR di atas rata-rata hanya 54 buah atau 54\% dari 100 BPR di Indonesia.

Tabel 5. Rata-rata Return On Asset (ROA) BPR di Indonesia Tahun 2015

\begin{tabular}{clcc}
\hline No. & Return On Asset (ROA & Frekuensi & Persentase \\
\hline 1. & ROA $<2,39$ & 41 & $41 \%$ \\
\hline 2. & ROA $>2,39$ & 59 & $59 \%$ \\
\hline \multicolumn{2}{l}{ Jumlah } & 100 & $100 \%$ \\
\hline Rata-rata & 2,39 & \\
\hline
\end{tabular}

Berdasarkan tabel di atas diketahui rata-rata Return On Asset (ROA) (Y) 2,39. Jumlah BPR yang mencapai ROA < 2,39 berjumlah 41 buah. Jumlah BPR yang mencapai ROA > 2,39 berjumlah 59 buah. Jadi jumlah BPR yang mencapai nilai ROA di atas rata-rata 59 buah atau $59 \%$ dari 100 BPR di Indonesia.

Hasil analisis regresi menunjukkan koefisien determinan Capital Adequacy Rasio dan Loan to Deposit Ratio terhadap Return On Asset. Nilai koefisien determinan atau R pengaruh Capital Adequacy Rasio dan Loan to Deposit Ratio terhadap Return On Asset Bank BPR di Indonesia senilai 0,74. Nilai $\mathrm{R}$ dikuadratkan sebesar 0,75. Ini maksudnyaReturn On Assetdipengaruhi Capital Adequacy Rasio dan Loan to Deposit Ratiosebesar 74\%. Sisanya sebesar 26\% dipengaruhi oleh variabel lain di luar penelitian ini.

Pengaruh Capital Adequacy Rasio dan Loan to Deposit Ratio terhadapReturn On Asset besar karena mencapai 74\%. Dengan demikian manajer Bank BPR perlu mempertimbangkan Capital Adequacy Rasio dan Loan to Deposit Ratiokarena keduanya memberikan kontribusi yang besar terhadap turun atau naiknya Return On Assetpada Bank BPR di Indonesia.

Uji $\mathrm{F}$ digunakan untuk menentukan pengaruh variabel independen terhadap variabel dependen. Selain itu Uji F juga digunakan untuk menguji ketepatan model penelitian. Jika F hitung $>\mathrm{F}$ tabel dengan signifikansi $<0,05$, maka pengaruh variabel independen terhadap variabel dependen terbukti dan model penelitian dianggap tepat atau layak. Nilai F hitung pengaruh Capital Adequacy Rasio dan Loan to Deposit Ratio terhadap Return On Asset 3,926 dengan signifikansi 0,023 . Nilai $F$ tabel pada df $1=2$ dan df $2=97$ sebesar 3,07. Nilai $F$ hitung $>$ F tabel dan signifikansi $0,023<0,05$. Dengan demikian, hipotesis yang menyatakan Capital Adequacy Rasio dan Loan to Deposit Ratioberpengaruh simultan terhadap Return On Asset diterima dan model penelitian ini sudah tepat atau layak. 
Tabel 6 Hasil Uji Regresi Linear

\begin{tabular}{lrrrrr}
\hline \multicolumn{1}{c}{ Variabel } & \multicolumn{1}{c}{ B } & Koefisien Regresi (b) & Standar Error & \multicolumn{1}{c}{ T } & Sig \\
\hline Konstanta & $-5,479$ & & 2.901 & -1.889 & 0,062 \\
\hline CAR (X1) & 0,019 & .072 & .026 & 0,733 & 0,465 \\
\hline LDR (X2) & 0,096 & .270 & .035 & 2,756 & 0,007 \\
\hline
\end{tabular}

Tabel di atas menunjukkan pengaruh parsial variabel Capital Adequacy RasiodanLoan to Deposit RatioterhadapReturn On Asset. Kriteria yang digunakan untuk menentukan pengaruh parsial adalah jika $t$ hitung $>\mathrm{t}$ tabel dan signifikansi $<0,05$ maka terdapat pengaruh parsial variabel bebas terhadap variabel terikat. Berdasarkan tabel di atas nilait hitung Capital Adequacy Rasioterhadap Return On Asset sebesar 0,733 dan t tabel 1,685 dengan signifikansi 0,462 . Nilai t hitung < tabel dan signifikansi 0,465 >0,05. Dengan demikian hipotesis yang menyatakanCapital Adequacy Rasioterhadap Return On Asset BPR di Indonesia ditolak. Pengaruh parsial Capital Adequacy terhadap Return On Asset BPR di Indonesia tidak signifikan.

Nilai t hitung Loan to Deposit Ratio terhadap Return On Asset sebesar 2,756 dan t tabel 1,685 dengan signifikansi 0,007. Nilai t hitung $>$ tabel dan signifikansi 0,007 <0,05. Dengan demikian hipotesis yang menyatakanLoan to Deposit Ratio terhadap Return On Asset BPR di Indonesia diterima. Pengaruh parsial Loan to Deposit Ratio terhadap Return On Asset BPR di Indonesia signifikan. Nilai beta $(\beta)$ pada tabel di atas dapat digunakan untuk menentukan variabel yang dominan memberikan pengaruh terhadap variabel terikat. Nilai $\beta$ yang lebih besar akan memberikan pengaruh dominan terhadap vaiabel indenpenden. Nilai $\beta$ Capital Adequacy Ratiomencapai 0,072. Nilai $\beta$ Loan to Deposit Ratio mencapai 0,270. Nilai $\beta$ variabel Loan to Deposit Ratio(X2) > nilai $\beta$ Capital Adequacy Ratio(X2). Jadi Loan to Deposit Ratio dominan mempengaruhi Return On Asset dibandingkan dengan Capital Adequacy Ratio.

Selanjutnya nilai $\beta$ tabel dapat membantu menentukan garis persamaan regresi. Persamaan garis regresi dapat memberikan penjelasan kenaikan masing-masing variabel independen mempengaruhi kenaikan variabel dependen.Nilai $\beta$ variabel Capital Adequacy Rasio (X1) 0,019danLoan to Deposit Ratio (X2) sebesar 0,096.Nilai konstanta 5,479 .Berdasarkan nilai konstanta dan $\beta$ ini disajikan garis persamaan regresi sebagai berikut.

$\mathrm{Y}=-5,379+0,019 \mathrm{X} 1+0,096 \mathrm{X} 2+\mathrm{e}$

Persamaan garis regresi di atas dijelaskan sebagai berikut :

1. Konstanta sebesar -5,379 menunjukkan Retunr On Asset $=15,379$, apabila variabel bebas dianggap konstan atau tidak berubah. Nilai Return On Asset $-5,379$ jika tidak terjadi peningkatan kompetensi dan pelatihan.

2. Nilai B Capital Adequacy Rasio (X1) 0,019 dapat dijelaskan bahwa apabila terjadi kenaikan skor Capital Adequacy Rasio (X1) sebesar satu satuan maka Rturn On Asset akan meningkat sebesar 0,019, jika variabel bebas lain dianggap konstan.

3. Nilai B danLoan to Deposit Ratio (X2) 0,096 dapat dijelaskan bahwa apabila terjadi kenaikan skordanLoan to Deposit Ratio (X2) sebesar satu satuan maka Return On Asset akan meningkat sebesar 0,096, jika variabel bebas lain dianggap konstan

\section{Diskusi}

Hasil penelitian ini membuktikan bahwa Capital Adequacy Ratio (X1) dan Loan to Deposit Ratio (X2) berpengaruh signifikan terhadap Return On Asset (Y). Keuntungan 
perusahaan dapat dilihat dari perhitungan rasio profitabilitas. Rasio profitabilitas merupakan rasio yang digunakan untuk mengukur kemampuan perusahaan dalam menghasilkan laba dari aktivitas normal bisnisnya. Tujuan operasional dari sebagian besar perusahaan adalah untuk memaksimalisasi profit baik profit jangka pendek maupun profit jangka panjang. Manajemen dituntut untuk meningkatkan imbal hasil (return) bagi pemilik perusahaan sekaligus juga meningkatkan kesejahteraan karyawan. Ini dapat dicapai apabila perusahaan memperoleh laba dalam aktivitas bisnisnya (Hery, 2015: 226).

Salah satu rasio keuangan yang digunakan untuk mengukur profit perusahaan adalah rasio profitability. Rasio profitability merupakan rasio untuk menilai kemampuan perusahaan dalam mencari keuntungan atau laba dalam suatu periode tertentu. Rasio ini juga memberikan ukuran tingkat efektivitas manajemen suatu perusahaan yang ditunjukkan dari laba yang dihasilkan dari penjualan atau dari pendapatan investasi. Dikatakan perusahaan rentabilitasnya baik apabila mampu memenuhi target laba yang telah ditetapkan dengan menggunakan aktiva atau modal yang dimilikinya. Rasio ini dapat diukur dengan menghitung Return On Asset (ROA).

Profitabilitas dapat diketahui melalui perhitungan Return OnAsset (ROA). ROA merupakan kemampuan dari modal yang diinvestasikan ke dalam seluruh aktiva perusahaan untuk menghasilkan keuntungan.Semakin tinggi laba yang dihasilkan, maka semakin tinggi pula ROA, hal itu berarti bahwa perusahaan semakin efektif dalam penggunaan aktiva untuk menghasilkan keuntungan.ROA dihitung berdasarkan perbandingan laba sebelum pajak dan rata-rata total assets.

Profitabilitas dapat diukur dengan ROA.ROA mengukur kemampuan manajemen bank dalam mengelola aset-asetnya guna memperoleh keuntungan secara keseluruhan (Dendawijaya, 2003: 120). Hasil pengembalian atas aset merupakan rasio yang menunjukkan seberapa besar kontribusi aset dalam menciptakan laba bersih. Dengan kata lain, rasio ini digunakan untuk mengukur seberapa besar jumlah laba bersih yang akan dihasilkan dari setiap rupiah dana yang tertanam dalam total aset. Semakin tinggi hasil pengembalian atas aset berarti semakin tinggi pula jumlah laba bersih yang dihasilkan dari setiap rupiah dana yang tertanam dalam total aset. Sebaliknya, semakin rendah hasil pengembalian atas aset berarti semakin rendah pula jumlah laba bersih yang dihasilkan dari setiap rupiah dana yang tertanam dalam total aset.

Penilaian didasarkan kepada permodalan yang dimiliki oleh salah satu bank. Salah satu penilaian yang biasa dilakukan adalah dengan metode CAR (Capital Adequacy Rasio), yaitu dengan cara membandingkan modal terhadap aktiva tertimbang menurut risiko (ATMR) (Kasmir, 2011: 273).

CAR adalah rasio atau perbandingan antara modal bank dengan aktiva tertimbang menurut resiko (ATMR). CAR menjadi pedoman bank dalam melakukan ekspansi di bidang perkreditan.Dalam prakteknya perhitungan CAR yang oleh Bank Indonesia disebut Kewajiban Penyediaan Modal Minimum Bank (KPMM) tidaklah sederhana.KPMM adalah perbandingan antara Modal dengan Aktiva Tertimbang Menurut Resiko (ATMR). Baik ATMR maupun Modal Bank memerlukan rincian dan kesamaan pengertian apa yang masuk sebagai komponen untuk menghitung ATMR dan bagaimana menghitungnya. Begitu juga Modal, perlu dirinci apa yang dapat digolongkan dan diperhitungkan sebagai Modal Bank. Petunjuk mengenai hal ini diatur dasar-dasarnya oleh Bank Indonesia melalui ketentuan SE BI No. 26/1/BPPP tanggal 29 Mei 1993.

Capital Adequacy Ratio (CAR) mempunyai fungsi untuk mengidentifikasi, mengukur, mengawasi, dan mengontrol risiko-risiko yang timbul yang dapat berpengaruh terhadap besarnya modal bank. Perhitungan capital adequacy ini didasarkan pada prinsip bahwa setiap penanaman yang mengandung risiko harus disediakan jumlah modal sebesar persentase tertentu (risk margin) terhadap jumlah penanamannya (Mudrajat Kuncoro, 2002: 562). CAR merupakan alat analisis yang digunakan untuk mengetahui berapa jumlah modal yang memadai untuk 
menunjang kegiatan operasionalnya dan cadangan untuk menyerap kerugian yang mungkin terjadi (Mudrajat Kuncoro, 2002: 573). Semakin tinggi CAR maka semakin tinggi modal sendiri yang dapat digunakan untuk mendanai aktiva produktifnya atau menutup risiko kerugian dari penanaman aktiva, sehingga semakin rendah biaya dana yang dikeluarkan oleh bank. Dengan demikian, semakin rendah biaya dana yang dikeluarkan maka laba bank akan semakin meningkat.

Batas bawah yang ditetapkan oleh Bank Indonesia untuk rasio LDR adalah 78\%, artinya jika bank umum menyalurkan kredit di bawah angka tersebut maka bank dianggap masih kurang efisien dalam penyaluran kredit. Namun apabila jumlah penyaluran kredit melewati batas atas yakni 100\%, maka bank tersebut dianggap terlalu agresif sehingga dapat meningkatkan eksposur risiko yang dihadapi Oleh karena itu, angka LDR bank harus dijaga (Kasmir, 2011: 290).

Penelitian Asmoro (2010) menunjukkan bahwa rasio keuangan CAR, NPL, ROA, BOPO, dan LDR memiliki daya klasifikasi atau daya prediksi untuk kondisi bank yang mengalami kesulitan keuangan, bank yang mengalami merger, dan bank yang mengalami kebangkrutan. Persamaan regresi yang dihasilkan adalah $\mathrm{Y}=-6,405-0,039 \mathrm{CAR}+0,022 \mathrm{NPL}-0,804 \mathrm{ROA}$ $+0,053 \mathrm{BOPO}+0,005 \mathrm{LDR}$. Dari hasil analisis menunjukkan hasil secara parsial bahwa variabel CAR dan ROA berpengaruh negatif dan signifikan terhadap kondisi bermasalah. Sedangkan variabel NPL, BOPO, dan LDR berpengaruh positif tetapi tidak signifikan terhadap kondisi bermasalah pada sektor perbankan. Kemudian hasil estimasi regresi logistik menunjukkan kemampuan prediksi dari 5 variabel bebas tersebut terhadap kondisi bermasalah sektor perbankan sebesar $49,1 \%$ sedangkan sisanya, yaitu sebesar 50,9\% dijelaskan oleh variabel lain di luar model.

Return On Asset dapat dipengaruhi oleh Capital Adequacy Ratio (CAR), Biaya Operasi dibanding Pendapatan Operasi, Net Interest Margin, NonPerforming Loan dan Loan to Deposit Ratio. Penelitian terdahulu dilakukan Prakasa (2007) membahas tentang Analisis Pengaruh Rasio-rasio Keuangan Terhadap Kinerja Bank Umum di Indonesia (Studi Empiris Bank-bank Umum yang Beroperasi Di Indonesia). Tujuan dari penelitian ini adalah untuk membuktikan pengaruh rasio keuangan Capital Adequacy Ratio, Biaya Operasi dibanding Pendapatan Operasi, Net Interest Margin, NonPerforming Loan (NPL) dan Loan to Deposit Ratio terhadap kinerja bank yang diukur dengan Return On Asset serta variabel-variabel manakah yang paling dominan berpengaruh terhadap Return On Asset.

Dari hasil uji F didapat nilai F hitung sebesar 158,074 dengan P value sebesar 0,001. Hal ini berarti nilai $\rho$ value kurang dari 0,05 yang menunjukkan bahwa variabel Capital Adequacy Ratio, Biaya Operasi dibanding Pendapatan Operasi (BOPO), Net Interest Margin, Non Performing Loan dan Loan to Deposit Ratio secara bersama-sama mempunyai pengaruh yang berarti terhadap Return On Asset. Berdasarkan hasil uji t disimpulkan bahwa Non Performing Loan, NetInterest Margin dan Biaya Operasi dibanding Pendapatan Operasi berpengaruh secara parsial terhadap Return On Asset sedangkan CapitalAdequacy Ratio dan Loan to Deposit Ratio tidak berpengaruh secara parsial. Tanda positif pada variabel Non Performing Loan dapat dijelaskan bahwa ROA pada tahun tersebut tetap tinggi meskipun nilai NPL juga tinggi. Hal ini dapat terjadi karena rata-rata NPL pada tahun tersebut masih dalam batas NPL maksimum yang disyaratkan oleh Bank Indonesia yaitu 4,14\% sehingga ROA tetap tinggi.

Penelitian Rindhatmono (2005) menganalisis Analisis Faktor-Faktor yang Mempengaruhi Profitabilitas Bank Pasca Merger di Indonesia.Kecenderungan bisnis untuk melakukan merger dan akuisisi, terjadijuga pada bisnis keuangan terutama bank. Di Indonesia, proses konsolidasiperbankan dilakukan melalui Arsitektur Perbankan Indonesia (API). Karena adanya perbedaan profitabilitas bank yang telah melakukan merger dan akuisisi dengan bank yang tidakmelakukan merger dan akuisisi, maka maksud dari penelitian ini adalah untuk 
menguji danmenganalisis pengaruh efisiensi usaha (BOPO), risiko kredit (NPL), risiko pasar (NIM), Likuiditas (LDR), market share (TA) dan modal (CAR) terhadap profitabilitas(ROA) bank pasca merger di Indonesia. Penelitian dilakukan terhadap bank yangtelah melakukan M dan A dengan pooling data dari tahun 1999-2004 dan dianalisisdengan metode regresi berganda.

Hasil penelitian menunjukkan bahwa BOPO, NPL, NIM, CAR dan market share mempunyai pengaruh yang signifikan terhadapprofitabilitas (ROA) bank pasca merger di Indonesia, sedangkan LDR tidak signifikan. Secara keseluruhan, bank pasca merger di Indonesia mempunyai ratio BOPO, NPL, NIM, LDR, CAR dan MS, belum dapat memenuhi batasan-batasan yang telahditetapkan oleh regulator. Hal ini membuktikan bahwa bank pasca merger di Indonesia yang telah melakukan merger sejak tahun 1999, belum dapat melaksanakan fungsi intermediasi secara optimal dan persoalan merger bukan merupakan permasalahan keuangan semata-mata, tetapi juga kepada persoalan nonfinansial.

Secara parsial Capital Adequacy Ratio (X1) tidak berpengaruh signifikan terhad Return On Asset. Loan to Deposit Ratio berpengaruh signifikan terhada Return On Asset. Capital Adequacy Ratio (X1) tidak berpengaruh signifikan terhadapReturn On Asset disebabkan modal yang diperhitungkan tidak dtentukan apakah model finansial atau modal fisik. Modal bisa berarti financial capital yaitu nilai uag dari aktiva dikurangi dengan nilai kewajiban yang merupakan kontribusi uang pemilik kepada perusahaan. Physical capital, yaitu modal difokuskan pada kemampuan fisik dari modal itu untuk memproduksikan barang dan jasa bukan pada nilai uangnya. Ukurannya adalah kapasitas produksi dari aktiva yang dimiliki (Harahap, 2011:305).

\section{Kesimpulan dan Keterbatasan Penelitian}

Berdasarkan analisis data dan hasil pembahasan penelitian ini, dapat dismpulkan sebagai berikut.

1. Capital Adequacy Ratio(X1) dan Loan to Deposit Ratio(X2) berpengaruh signifikan secara simulan terhadap Return On Asset (Y).

2. Capital Adequacy Ratio(X1) berpengaruh tidak signifikan secara parsial terhadap Return On Asset (Y) pada Bank BPR di Indonesia.Loan to Deposit Ratio(X2) berpengaruh signifikan secara parsial terhadap Return On Asset (Y) pada Bank BPR di Indonesia.

3. Loan to Deposit Ratio(X2) berpengaruh dominan terhadapReturn On Asset (Y) dibandingkan denganCapital Adequacy Ratio(X1) pada Bank BPR di Indonesia.

\section{DAFTAR PUSTAKA}

Alma, Buchari.2008. Pengantar Bisnis. Bandung: Alfabeta.

Sanusi.A. 2012. Metodologi Penelitian Bisnis. Jakarta; Salemba Empat.

Arikunto, Suharsimi. 2010. Prosedur Penelitian. Jakarta: Rineka Cipta.

Asmoro, A. 2010.Analisis Pengaruh Rasio Keuangan terhadap Prediksi Kondisi Bermasalah pada Bank (Studi Kasus pada Bank Persero dan Bank Umum Swasta Nasional Periode 20042007). Semarang: Fakultas Ekonomi Universitas Diponegoro.

Harahap, Sofyan Syafri. 2011. Teori Akuntansi. Jakarta: PT RajaGrafindo Persada

Harmono. 2014. Manajemen Keuangan. Jakarta: Bumi Aksara.

Hery. 2015. Analisis Laporan Keuangan. Yogyakarta: CAPS.

Kasmir. 2011. Manajemen Perbankan. Jakarta: PT RajaGrfindo Persada

Kasmir. 2015. Analisis Laporan Keuangan. Jakarta: Rajawali Pers.

Kurniawan, Albert. 2014. Metode Riset untuk Ekonomi dan Bisnis. Bandung: Alfabeta.

Manulang, M. 2008. Pengantar Bisnis. Yogyakarta: Gajah mada Press.

Mudrajad, Kuncoro. 2002. Manajemen Perbankan: Teori dan Aplikasi. Yogyakarta: BPFE. 
Rindhatmono (2005) menganalisis Analisis Faktor-Faktor yang Mempengaruhi Profitabilitas Bank Pasca Merger di Indonesia.Tesis. PROGRAM STUDI MAGISTER MANAJEMEN PROGRAM PASCA SARJANA UNIVERSITAS DIPONEGORO SEMARANG

Sugiyono. 2008. Metode Penelitian Administrasi. Bandung: Alfabea.

Surat Edaran Bank Indonesia No.13/30/DPNP tanggal 16 Desember 2011. Perihal Laporan Keuangan Publikasi Triwulan dan Bulanan Bank Umum yang Disampaikan kepada Bank Indonesia. Diakses dari www.bi.go.id padatanggal 23 Februari 2014. 